\title{
Urban development after the Bosnian War: The division of Sarajevo's territory and the construction of East Sarajevo.
}

Inés Aquilué \& Estanislao Roca

Department of Urban and Regional Planning, Universitat Politècnica de Catalunya, Av. Diagonal, 649, 08029, Barcelona, Spain

ines.aquilue@upc.edu; estanislao.roca@upc.edu

\section{Introduction}

There are many cities in the world that suffer from conflicts between communities, where violence occurs between diverse ethnicities with opposing nationalist convictions. In Jerusalem, Belfast, Nicosia, Mostar, Johannesburg and Sarajevo ethnic conflicts have led to the division of the city, promoting circumstances that profoundly mark their development (Benvenisti, 1982, 1986; Bollens, 1999, 2000, 2007; Calame \& Charlesworth, 2009; Klein, 2001; Marcuse, 1993; Sorkin, 2002). The existence of a frontier creates specific spatial and social meanings. Border cultures arise and produce divergent, though not always exclusive, attitudes ranging from the glorification of national differences to fluid economic exchange (Donnan \& Wilson, 1999). From this it may be seen that there is a broad spectrum of divisions which do not always lead to similar patterns. The question as to whether Sarajevo is a truly divided city has many answers, some of which are contradictory, given that the socio-political and geographic reality affecting the present capital of Bosnia and Herzegovina is complex and difficult to classify.

The current situation in Sarajevo represents an urban paradigm caused by the Bosnian War that took place during the 1990s. Preceded by the war in Croatia, the armed conflict in Bosnia and Herzegovina (April 1992 - December 1995) was exposed to the manoeuvring of both internal and external leaders across a territory mainly composed of three ethnic groups: Bosniaks (Bosnian Muslims), Serbs and Croats (Silber \& Little, 1996). Bosnia and Herzegovina became the shock absorber between Serbs and Croats until its own self-determination led to the outbreak of inter-ethnic conflict (Andjelić, 2003). Sarajevo was besieged by the forces of the Army of Republika Srpska (VRS) and the Yugoslav People's Army (JNA) who isolated the city provoking a state of emergency that lasted for 1,425 days and cost 11,541 lives. ${ }^{1}$ The end of the conflict led to the internal division of Bosnia and Herzegovina $(\mathrm{BiH})$ into two new entities, the Federation of Bosnia and Herzegovina ( $\mathrm{FBiH}$ ) and the Republika Srpska (RS). This involved the construction of a state structure deeply conditioned by the treaty which ended the war (Bose, 2002), known as the Dayton Peace Agreement (DPA) which determined the limit between the RS and the FBiH, called the Inter-Entity Boundary Line (IEBL). This brought about modifications to both the social and spatial structures of the city, creating an urban centre pertaining to the Federation with an ethnic Bosniak majority, and a number of suburbs in the east, of largely Serbian ethnicity, which became part of the Republika Srpska (Bollens, 2000).

Indeed, in Sarajevo the main geopolitical factors that have determined the territorial and urban situation after the war appear to be the following: First, the necessary and imminent rebuilding and restructuring of institutions, infrastructures and buildings (both public and private) (Bădescu, 2014; Garcia \& Kotzen, 2014; Hasić, 2004). Second, the change of economic model from the socialist system to the neoliberal and capitalist system and as a result, the entry of foreign investment which would lead to globalisation and is frequently connected to Turkish and Arabic capitals. (Karčić, 2010a, 2010b). Third, the territorial division of Bosnia into two entities and the consequent displacement of the population from one region to another (Toal \& Dahlman, 2011). ${ }^{2}$ Following the war, the urban development of the city was determined above all by physical, social, administrative and structural recovery. It should be born in mind that after an armed conflict, this recovery must deal not only with the devastated environment, but also with restoring the physical and social fabric of the city, with structural reform through creating and/or eliminating parts of the administration and with reorganising the system of institutional headquarters (Kumar, 1997). Furthermore, in the case of the post-war period in Yugoslavia, the city had to confront not only territorial division and the devastation of war, but also the sudden occurrence of radical political and economic change. With the break-up of Yugoslavia, Socialism also dissolved. The cities of the former Yugoslavia lost their old socialist status and entered into a process of profound restructuring similar to the other states of Eastern Europe (Andrusz et al., 1996).

Whilst some post-socialist cities have been analysed both physically and economically (Andrusz et al., 1996; Hirt, 2006; Hirt, 2008; Kovács, 1999, Stanilov, 2007; Tsenkova \& Nedović-Budić, 2006; Tsenkova \& Polanska, 2014), the urban study of the Bosnian cities has scarcely touched on the impact produced by the changeover to the capitalist system (Martín-Díaz, 2014). Eclipsed by the devastation of war, the transition to capitalism has still not become a subject of in-depth debate. Economic studies concentrate mainly on the country's state of emergency and its development based on the Priority Reconstruction for Recovery Program (PRRP) managed by the World Bank. ${ }^{3}$ The difficulty of creating a holistic socio-political analysis is understandable given the combination of the similar conditions brought about by the post-socialist and post-war context.

Many of the reconstruction projects in Bosnia and Herzegovina have been developed by non-governmental organisations (Garcia \& Kotzen, 2014) and under the strong presence of the International Community (IC) which has intervened in the politics of development as much in economic as in

\footnotetext{
1 Sarajevo was the site of the longest siege of a European city in contemporary history. For further detail, see the Fama Collection: http://www.famacollection.orgl and anthropological studies by Andreas (2008), Maček (2000, 2009) and Softić (1994).

${ }^{2}$ As explained below, this process began with the outbreak of the war and has continued to a lesser degree although without being forced displacement, up to the present day.

${ }^{3}$ By way of example, the First EU/World Bank Donors' Conference for BiH in Brussels launched the $\$ 5.1$ billion Priority Reconstruction Program, and an initial $\$ 600$ million was pledged. See: http://www.ohr.int/ohr-info/key-events/default.asp?content id=35971.
} 
political terms at the heart of the new state (Bose, 2002). The framework of reconstruction has centred on repairing that which had been destroyed, reconstructing symbolic buildings and historic city centres, relegating to the background other more structural needs linked to the ethnic divide. However, this activity is becoming insufficient in the mid and long term, above all in cities with territorial divisions marked by inter-ethnic problems (Calame \& Charlesworth, 2009).

Of the three main factors which affected Sarajevo after the war, this article focuses on analysing the consequences that the internal boundary of Bosnia and Herzegovina has on the urban development of the city, in order to discover both its effect on planning and the human and geographic consequences of the division of the old territory of the urban and peripheral areas of Sarajevo. The case of Sarajevo differs from that of other divided cities, such as Jerusalem, Mostar, Nicosia, Beirut and Belfast (Calame \& Charlesworth, 2009). In Sarajevo, the consolidated central urban area has been left untouched by the territorial dividing line, which, up to the present moment, has remained as an administrative limit. Given this basic determining factor, the aim of this article is to demonstrate how the existence of an administrative limit may determine the development of the city in the present and in the future, in spite of its physical non-existence and its apparent permeability. The situation in the region is analysed at different scales (from the scale of planning to that of ethnography) in order to demonstrate that although the IEBL neither divides the historic city nor is a physical frontier, contrasting processes of homogenisation do exist on each side of the border which maintains a significant social and morphological differentiation.

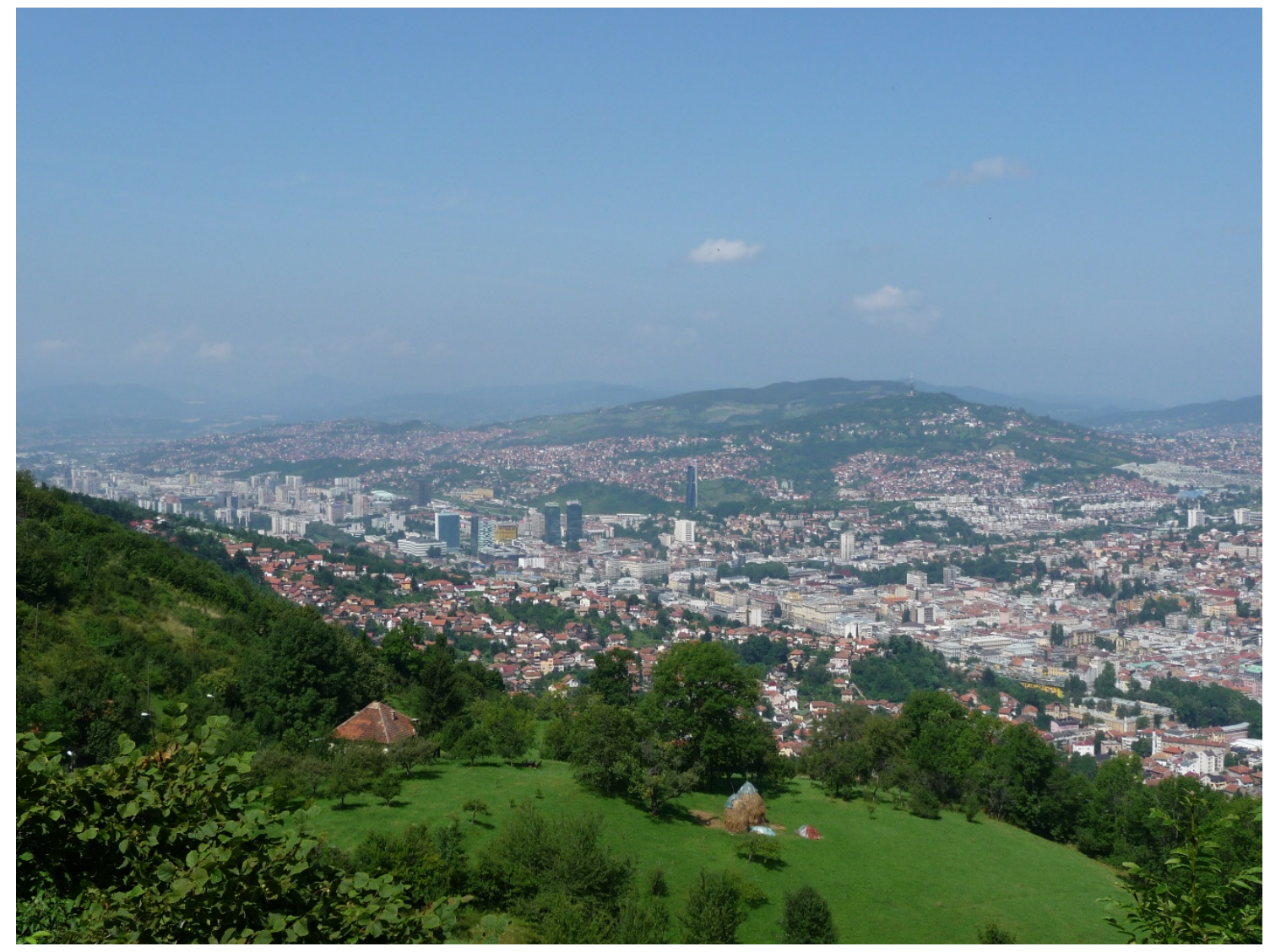

Fig. 1. View of Sarajevo (FBiH) from Mount Trebević (FBiH - RS), the city in the Miljacka river valley, February 2014. Source: The authors.

\section{The territorial division of Bosnia-Herzegovina, population displacement and resettlement in the city of Sarajevo}

Sarajevo's urban growth up until 1992 had followed the procedures of the various empires, kingdoms and states which had governed the region one after another. In this regard, the city had developed gradually following the precedents of higher authorities: The Ottoman Empire (1462-1878), the Austro-Hungarian Empire (1878-1918), the Kingdom of Yugoslavia (1918-1945) and the Socialist Federal Republic of Yugoslavia (SFRY) (19451992) (Bublin, 2006; Donia, 2006; Kurto, 1998; Gül \& Dee, 2015). Over time, the city became the main urban area in the central part of Bosnia, thanks to the periods of intense urbanization during the first stages of industrialization (led by the government of the House of Habsburg) and extremely rapid expansion during the socialist period (Andjelić, 2003), when the change in the production model led to an unprecedented exodus from rural areas to the city, quadrupling its size -in 1948, $72 \%$ of the population of Bosnia lived in rural communities, but by 1971 this had reduced to 36.6\% (Donia, 2006). The construction of the city followed the course of the Miljacka river both longitudinally and diachronically (see Fig. 1). The start of the war in Bosnia marked a rupture in the development of the city and changed the course of its evolution. One of the greatest administrative changes of the post-war period was that for the first time in its history, Sarajevo became the capital of an independent state. 


\section{The division of Bosnia-Herzegovina}

The Bosnian War turned into a territorial dispute that seriously affected its internal borders. Whilst it is acknowledged that Franjo Tudjman and Slobodan Milošević attempted to annex parts of Bosnian territory into Serbia and Croatia, the borders of the Republic remained intact. The European Commission (EC) intervened and arranged that despite the armed conflict between the different republics of the SFRY, their borders would only be modified by mutual consent, or would otherwise be protected by international law (Klemenčić, 1994:18). Whilst the external border was respected territorially, the inter-ethnic dispute over territory ended up with internal fragmentation (see Fig. 2). By 1991, and also during the war, various proposals had arisen for internal divisions connected to the ethnic homogenisation of one territory or another (Klemenčić, 1994), but it was not until the DPA in December 1995 that Bosnia and Herzegovina was divided into the Republika Srpska, with 49\% of the territory and a Serbian majority, and the Federation of Bosnia and Herzegovina, ${ }^{4}$ with $51 \%$ of the territory and with a Bosniak and Croat majority. The latter was also subdivided into ten cantons (see Fig. $2 b$ ). The country of only $51,129 \mathrm{~km}^{2}$ was conditioned by this appearance of new entities, which had not existed before 1991 . The nature of the agreement maintained an interethnic segregation inside the boundaries of Bosnia and Herzegovina, and so the socio-demographic recuperation of the region became only partially possible. The DPA marked the end of the war but resolved neither the ethnic conflict nor its recomposed demographic impact.
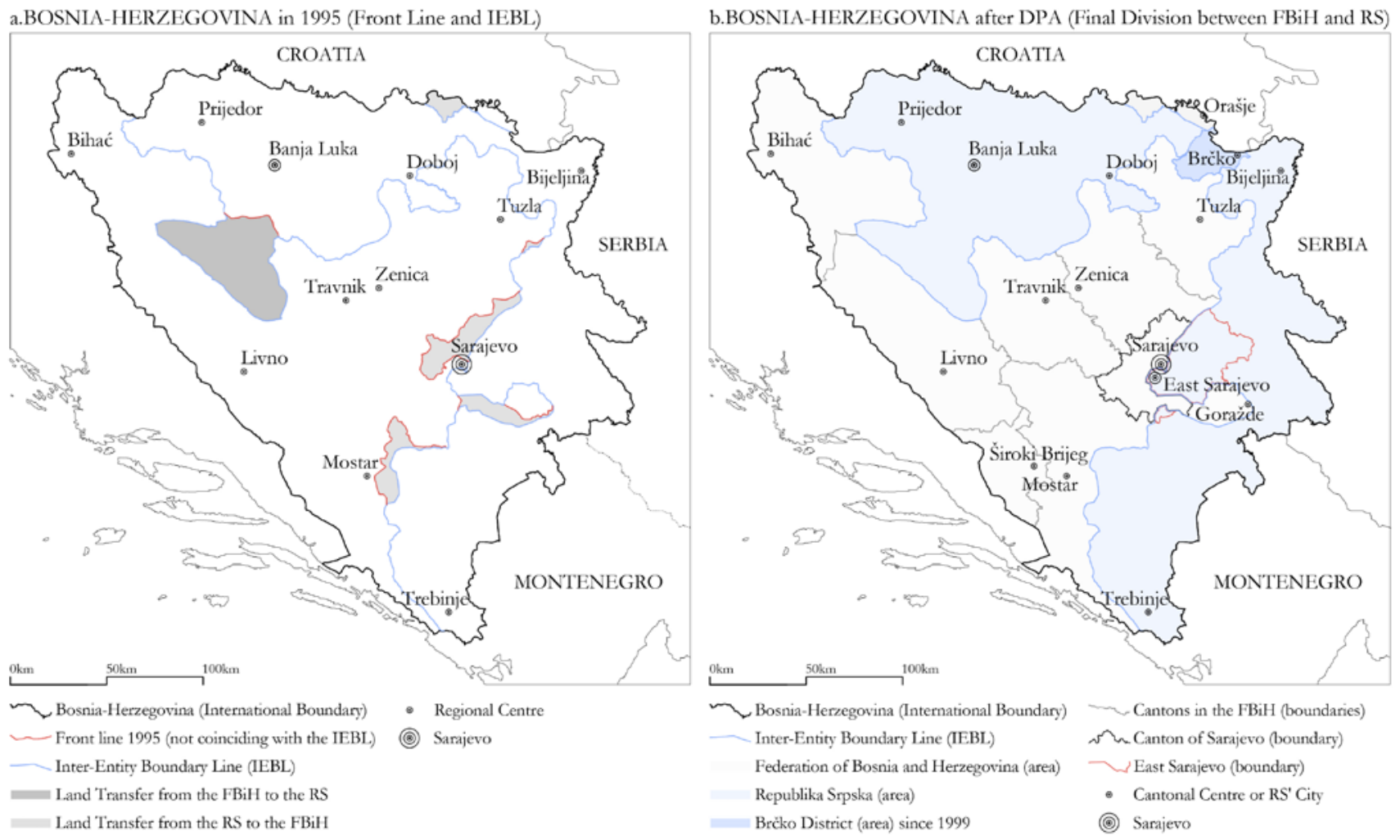

Fig. 2. Bosnia and Herzegovina in 1995 (front line) and the independent state of Bosnia and Herzegovina following the DPA, subdivided into the Republika Srpska, the Federation of Bosnia and Herzegovina (with its ten cantons) and the district of Brčko. Source: the authors.

The construction of the new political system was determined by the existence of three administrative levels in the RS, those of the municipality, the entity and the state, and four levels in the $\mathrm{FBiH}$, with the municipality, the canton, the entity and the state. Each of these levels has its own executive judicial and legal bodies, as well as triple ethnic representation (Bosniak, Croat and Serb) at presidential and ministerial level (Bose, 2002). This situation has caused a certain degree of dysfunction in the State, weakened by the strong ethnic identities of the entities, by the improvised character of the State's structures and by the external political interference (Bose, 2002; Jeffrey, 2012). Furthermore, a chamber of control was created, the Office of the High Representative for Bosnia and Herzegovina $(\mathrm{OHR})^{5}$-with a seat in Sarajevo- and a Peace Implementation Council (PIC), ${ }^{6}$ which supervised the implementation and fulfilment of the DPA, a supposedly temporary agreement which was intended to remain in force until the State

\footnotetext{
${ }^{4}$ As well as the two Entities, the RS and the FBiH, in March 1999, the Final Award constituted the District of Brčko, which belongs to both entities but is administratively independent. For further information see Jeffrey (2006).

5 The Sarajevo OHR Office was established in January 1996, when the First High Representative, Carl Bildt, and his German Deputy, Michael Steiner, arrived in Sarajevo. See: http://www.ohr.int/ohr-info/key-events/default.asp?content id=35971

${ }^{6}$ For further information about the PIC communiqués, see: http://www.ohr.int/picl, and for the implementation of IFOR forces and its substitution by SFOR see: http://www.nato.int/sfor/index.htm
} 
had become stabilised (Jeffrey, 2012). Twenty years later the DPA remains the administrative basis for the Entities, whilst the instability of the State is felt by the population with great concern. ${ }^{7}$

\section{Human displacements and their consequences within the urban area of Sarajevo}

As well as the territorial division and international interference in Bosnian politics, the war produced large displacements of the population caused by ethnic cleansing and by the internal displacement within areas which were gradually occupied by the VRS and the JNA (Burg \& Shoup, 1999; Toal \& Dahlman, 2011). In 1996, there were 1.2 million Bosnian refugees abroad spread across 25 countries, on top of which there were 1 million internal displaced people (DI), in a total population of 4.3 million in 1991 (ICG, 1997). Aware of the large migratory component caused by the war, the DPA included a specific annex to rehouse those displaced, Annex VII: "all refugees and displaced persons have the right freely to return to their homes of origin" (UN, 1995:94). This was ratified by the constitution of Bosnia which decreed the freedom of movement within state borders (Toal \& Dahlman, 2011:172). However, the return of the population did not occur as the agreement had foreseen. The fear of returning to their places of origin, where the displaced ethnicity was in the minority, and the violence perpetrated by some groups (particularly the police of the RS) caused a lack of equality in the recovery of the Bosnian population (Toal \& Dahlman, 2011:169-170). It is estimated that between 1991 and 1996 the Bosniak and Croat population in the RS controlled territory dropped from 840,000 to 73,000 , passing from $47.5 \%$ to $8.7 \%$ (Burg \& Shoup 1999). These population displacements led to serious human and geographic changes across the entire country and equally in its capital, as the Bosnian refugees who arrived in Sarajevo remained there until after the war (Stefansson, 2007).

These internal displacements had essentially two spatial consequences on the urban and regional areas of Sarajevo (ICG, 1997; Toal \& Dahlman, 2011). In Sarajevo informal housing settlements began to be built on the hills of the Miljacka river valley (see the hills in Fig. 1) because of the arrival of Bosniaks from areas occupied by the VRS and later from areas of the Republika Srpska -the area occupied by Serbobosnian forces in Autumn 1995 differs in part from the current RS (see Fig. 2a). The second consequence was caused by the displacement of the Serbobosnian population of the Sarajevo of the Federation towards the area controlled by the RS on the other side of the IEBL. This led to the construction of East Sarajevo (Istočno Sarajevo in Bosnian, Serbian and Croat), a new urban nucleus adjacent to the suburb of Dobrinja ${ }^{8}$-in the municipality of Novi Grad- and to the municipality of llidža, which even during the war formed part of the RS and took the name of 'Srpsko Sarajevo' (Serbian Sarajevo). ${ }^{9}$

On the one hand, it is estimated that the Sarajevo of the Federation has become an almost mono-ethnic city, with Bosniaks making up more than $87 \%$ of the population, and the remainder formed basically by a Croat minority (Bădescu, 2014). Many of the families displaced by the conflict that arrived from other parts of Bosnia lived in the hills. The illegal sale and occupation of land led to the extreme proliferation of informal housing being built (Aganović \& Krzik, 2006). The urban typology of these settlements was no more than a chain of individual single family houses built on unstable ground with high risk of landslides, and without basic services, un-made roads, non-existent or inadequate drainage, no educational facilities and ineffective public transport (Fig. 3 left).
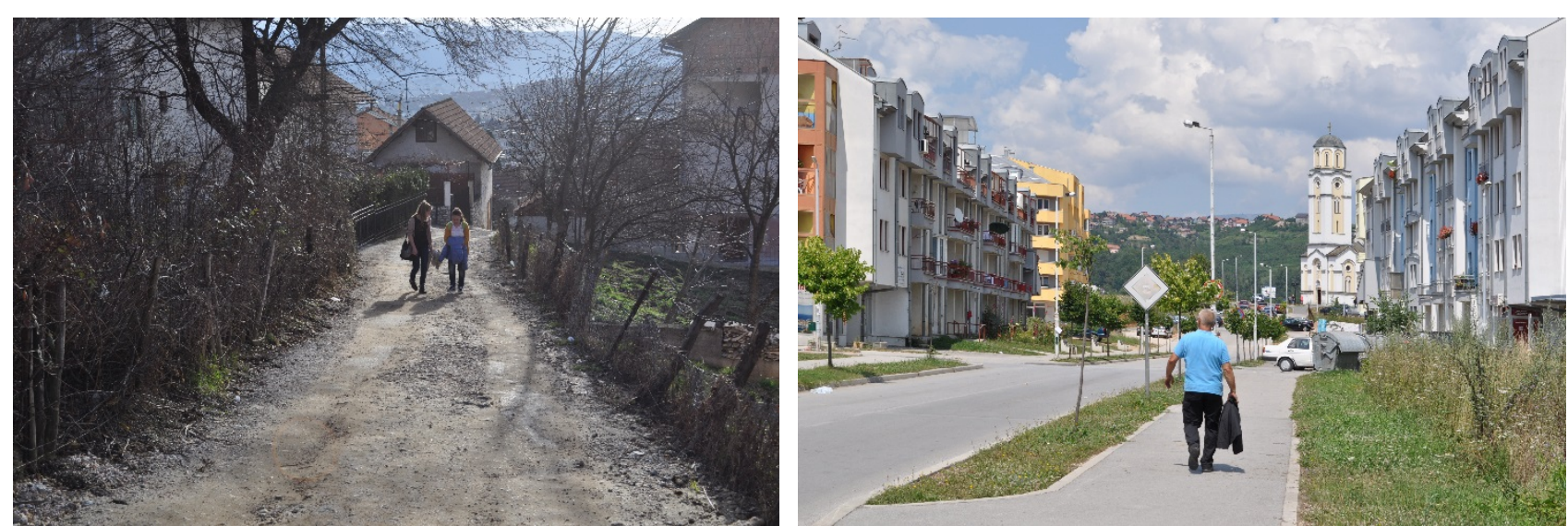

Fig. 3. Left: Informal settlements in the hills of Sarajevo, February 2014. Right: East Sarajevo under construction, August 2014. Source: the authors.

On the other hand, the institutions of the RS have promoted the construction of a new Sarajevo on the other side of the IEBL. Although the capital de facto of the RS is Banja Luka, the capital de iure is Sarajevo. According to article 9 of the first part of the Constitution of the Republika Srpska: "The capital of the Republika Srpska is Sarajevo" (National Assembly of Republika Srpska, 1992). In fact, the government of the RS never managed to locate its structures of state in Sarajevo, all of which have been concentrated in Banja Luka (Donia, 2006). The construction of the "other Sarajevo" is an utterly current desire. The location and development of this second alteration caused by the settlement of the Serbobosnian population at the

\footnotetext{
${ }^{7}$ This social alarm manifested itself in February 2014 with demonstrations in some of the largest Bosnian cities including Tuszla, Mostar, Zenica and Sarajevo, against the ineffectiveness of the regional government.

${ }^{8}$ Dobrinja is a neighbourhood alongside the airport built for the Winter Olympics of 1984 and which, until 1992, had been the most extensive district of the city. During the war this was severely affected by its location and was one of the most isolated areas within Sarajevo (Bećirović, 2002; Berman, 2005, 2007; Maček 2009).

9 Until 2004, the city was called Srpsko Sarajevo (Serbian Sarajevo) but the Constitutional Court of Bosnia and Herzegovina declared the name to be unconstitutional and the National Assembly of the Republika Srpska changed it to Istočno Sarajevo (East Sarajevo).
} 
edge of the IEBL, appears to be strongly determined by the design of the IEBL and the DPA, and is the result of the RS's wish to build its own Sarajevo.

\title{
2. The impact of the IEBL on Sarajevo and its consequences for the planning behind the DPA.
}

\author{
The artificiality of the IEBL and the division of the former City of Sarajevo
}

Annex II of the DPA described and legislated the limit between the two entities and also specified the measures to be taken to define the border and the process of transition in cases where land was to be transferred from one entity to the other (see Fig. 2a). The appendix attached to Annex II included an UNPROFOR road map to scale 1:600,000 onto which the boundary line was drawn. It also cited the obligatory future inclusion of a topographic line map to scale 1:50,000 onto which the exact position of the border would later be defined, and which all parties would have to accept within a margin of tolerance of $50 \mathrm{~m}$ (UN, 1995).

Due to the very nature of the IEBL, the boundary line was utterly alien to the physical and social environment. In the case studies of divided cities analysed by Calame and Charlesworth (2009), boundaries appear along lines of historic significance, a pattern they have termed "boundary etching". In Sarajevo, the IEBL did not originate from historic lines, but rather was designed during negotiations thousands of miles away from Bosnia and Herzegovina. The boundary line was in fact purely a pragmatic solution that accepted the existing front lines following the Croat-Muslim offensives in the autumn of 1995 (Klemenčić, 2000-2001). Without the DPA the Republika Srpska would make no sense (Klemenčić, 2000-2001).

The result was that the IEBL dissected part of the peripheral urban area diminishing the central city's zone of influence over the surrounding suburbs. Following the DPA, in the FBiH, the Canton of Sarajevo replaced the former City of Sarajevo and lost $39 \%$ of its original territory, while in the RS, the new city of East Sarajevo appeared, made up of the territory lost by the Canton plus the municipality of Sokolac (see Fig. 4 and Fig. 5). Analogous with what had occurred in Bosnia, the territory of the former City of Sarajevo was subdivided into two halves: The Canton of Sarajevo and East Sarajevo. This division of the city led to changes in its ethnic distribution. The region composed of the three main ethnic groups (Bosniaks, Serbs and Croats) became two territories: the Canton, with a Bosniak majority, and East Sarajevo with a Serbian majority. The re-composition of these ethnically divided and self-enclosed sectors is considered to be a process of "clustering" whereby ethnic groups tend to feel protected by enclosing themselves (Calame \& Charlesworth, 2009).
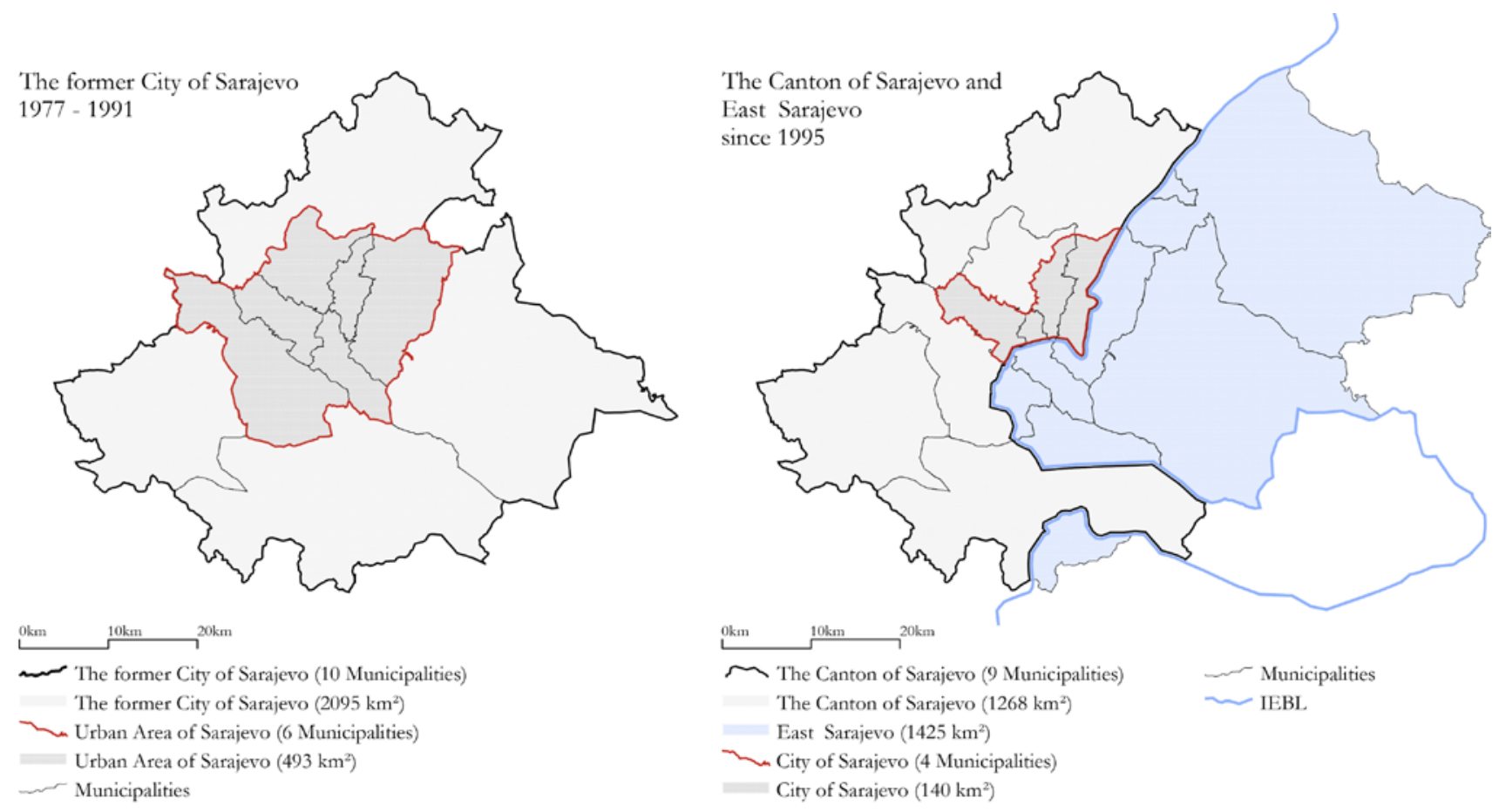

Fig.4. The urban region of Sarajevo in 1991 and the Canton of Sarajevo after 1995. Source: The authors

The artificial nature of the boundary has modified the status of the city and it's planning, breaking both its historical and morphological lineage and distancing itself from the relationship between its natural environment and its man-made interventions. The lack of precision in the IEBL caused a tedious situation in those geographic areas where it was necessary to exchange territory for the IFOR or where the route of the line was not sufficiently clear (Toal \& Dahlman, 2011; Jeffrey 2006, 2012; Sheridan, 2001). The path of the IEBL led to the accumulation of disputes and controversies over the definition of what territory belonged to the RS and what belonged to the Federation within the former City of Sarajevo. The difficulty involved in determining the position of the demarcation line provoked serious disagreement over the territory of the south-east urban area in the suburb of Dobrinja, adjacent to what would later become the new urban nucleus of East Sarajevo. The OHR had to intervene in order to define 
the position of the IEBL in this suburban area. The definitive path was designated in April 2001 by the Arbitration Award for Dobrinja I and IV, a sentence given by Diarmuid P. Sheridan, the judge selected by the High Representative (HR) (Sheridan, 2001). The arbitrator himself clearly expressed the difficulty involved for both parties to reach agreement bearing in mind the scale of the DPA maps.

"While I am sanguine with the Agreement and the various Annexes appended thereto, I am far from satisfied with the maps. The parties in Washington and Dayton were under great strain and the map chosen in the first instance, I am informed, was a map to a scale of 1:600,000. Why this particular scale was chosen is not clear to me. Because while it would be perfectly adequate to delineate the boundaries of the Entities over the whole spectrum, the fact would have to remain that the City of Sarajevo would merely appear as a dot" (Diarmuid P. Sheridan, Arbitrator for Dobrinja IEBL, 17th April 2001).

\section{Planning in the Sarajevo of the Federation of Bosnia and Herzegovina after the DPA}

These changes in political borders directly affected the development of Sarajevo and the planning processes involved. Before the war, the planning of the city had been based upon documents drawn up under the framework of the 30 year development plan for the period between 1986 and 2015 (Bublin, 2006). The two documents drawn up by the Socialist administration were the Spatial plan of the City of Sarajevo for the period 1986 - 2015 and the Urban plan of the City of Sarajevo for the urban area of Sarajevo, for the period from 1986 to 2015. These two documents went together and were produced at the same time by the Office for Development Planning of the City of Sarajevo. They identified two overlapping areas of intervention at different scales (City of Sarajevo, 1986a; City of Sarajevo, 1986b).

However, from the decade of the 2000s on, and after the sentence of the Arbitration Award for Dobrinja I and IV in 2001, the territorial division led to a change in the planning model. The appearance of the new entities provoked the need to make new plans that responded to the newly drafted boundary lines. In the Federation, the Office for Development Planning of the Canton of Sarajevo ${ }^{10}$ decided to start work on a new spatial plan for the territory of the Canton (Canton of Sarajevo, 2006). ${ }^{11}$ This regional plan published in 2006, at a scale of 1:50,000, was intended for the period 20032023. The loss of territory is one of the determining factors behind the cantonal plan whereby the ten municipalities were reduced to nine, and another four municipalities were subdivided. Consequently, Pale came to form part of the RS and Stari Grad, Novo Sarajevo, llidža and Trnovo were divided. These four municipalities retained their names in the FBiH whilst in the RS, they added the qualifying suffix istočni, meaning east (see Fig. 5). The density of the Canton of Sarajevo became much higher than that of the city of East Sarajevo, 345.6 inhabitants per km² versus 45.57 (see Fig. 5). This is because Sarajevo in the FBiH has kept the traditional urban areas, those which were constructed during the Ottoman and AustroHungarian periods as well as the majority of those dating from the Socialist era. The direct result of this is that the current city of Sarajevo unites four municipalities, which are not only the most populous (Stari Grad, Centar, Novo Sarajevo and Novi Grad), but also the most intense in terms of politics, institutions, tourism and international visibility.

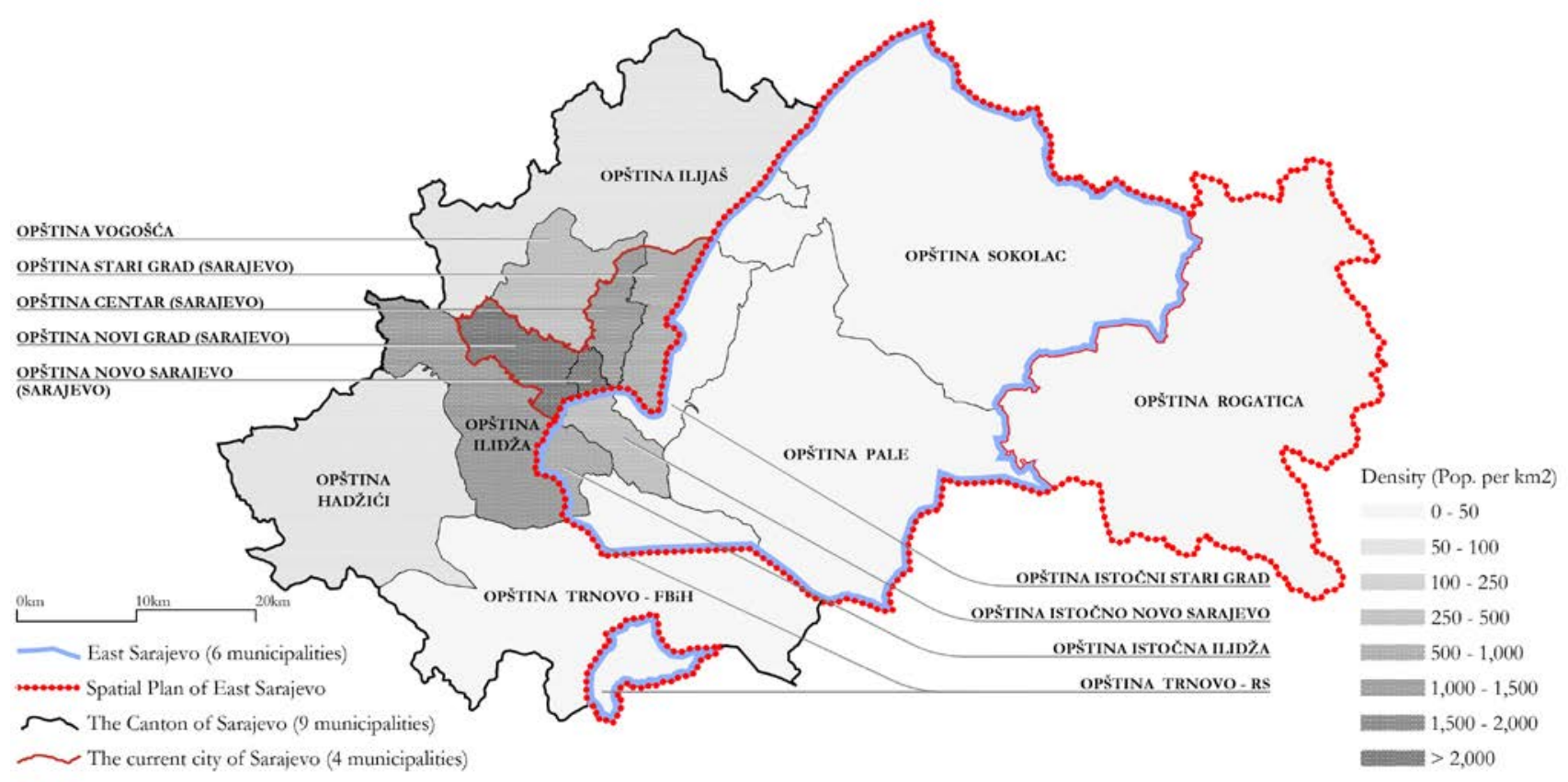

Fig. 5. Municipalities belonging to the Canton of Sarajevo and to East Sarajevo and their population densities. Source: the authors.

10 The Office for Development Planning of the City of Sarajevo changed its name after the war to The Office for Development Planning of the Canton of Sarajevo (http://zpr.ks.gov.bal).

11 The administration of the Canton of Sarajevo intends to promote strategic planning at this scale as an instrument for development. See Kurtović et al. (2013). 
Despite the publication of the cantonal plan in 2006, the urban plan of 1986, drawn at a more precise scale, still regulates the central urban area of Sarajevo. It is noticeable that in spite of the changes that have arisen throughout the Bosnian territory, which have seriously affected regional planning, the situation at the level of urban planning seems to remain frozen. Since the war, no new urban masterplan has been made and consequently the existing planning documentation at the urban scale conforms to that made in 1986 -revised in 1990 and 1998- (City of Sarajevo, 1986b). However, although this plan is still in force, new urban developments have introduced a number of morphological transformations in the inner city, mainly due to foreigner investors who have built new shopping malls and residential and office towers (Gül \& Dee, 2015; Martín-Díaz, 2014). In fact, the urban plan of 1986 still classifies zones that are currently part of the RS (see Fig. 6), although, as described below, they have been developed more recently according to new plans drawn up in the RS.

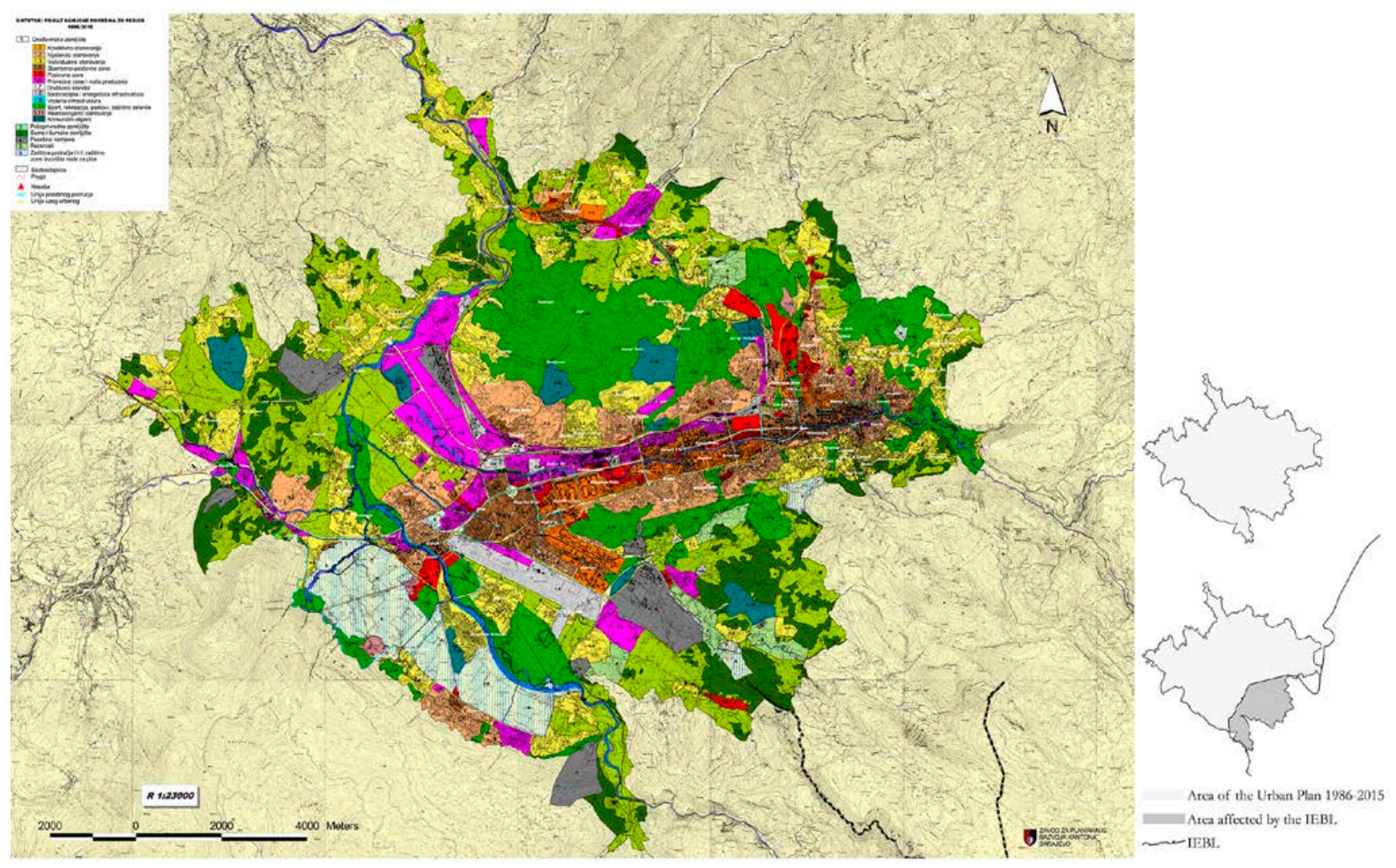

Fig.6. Urban Plan of the City of Sarajevo 1986-2015. Original scale 1:23,000. Source: $\underline{\text { http://zpr.ks.gov.bal }}$

Planning processes in the Republika Srpska and in East Sarajevo after the Arbitration Award.

On the other side of the IEBL, planning at a regional level is defined not by a cantonal plan, but by a spatial plan covering the whole of the RS. In the $\mathrm{RS}$, the boundary with the FBiH has been newly reinforced by the approval of amendments to the previous spatial plan presented in Banja Luka in the spring of 2014 (National Assembly of Republika Srpska, 2014). The Amendments of the Development Plan for the Republika Srpska to 2025 drawn at 1:200,000 shows the prospects for development in the RS in a manner utterly different to that employed in the regional plan for the Canton of Sarajevo. The development plan for the Republika Srpska affects the former City of Sarajevo given that it reaffirms the existence of East Sarajevo. This plan recognises the various urban agglomerations of the RS and designates Prijedor, Banja Luka, Doboj, Bijeljina, East Sarajevo and Trebinje as cities (see Fig. 7 in purple and orange from west to east, and north to south). The regional plan unifies various historic urban enclaves in order to form the new city of East Sarajevo, some of which are moderately populous (East llidža, Pale, Lukavica) whilst others have only small populations (Hreša in East Stari Grad, Trnovo, Sokolac). The creation of this plan for urban prospecting not only stabilises the entity, whilst continuing the duplication of administration between Sarajevo and the new East Sarajevo (Bassi, 2013), but also equates the new city with the five other cities situated in the territory of the RS (those mentioned previously), which already existed and formed part of the administrative framework of the old Yugoslavia before the DPA (see Fig. 2a) (Malcolm, 1994). 


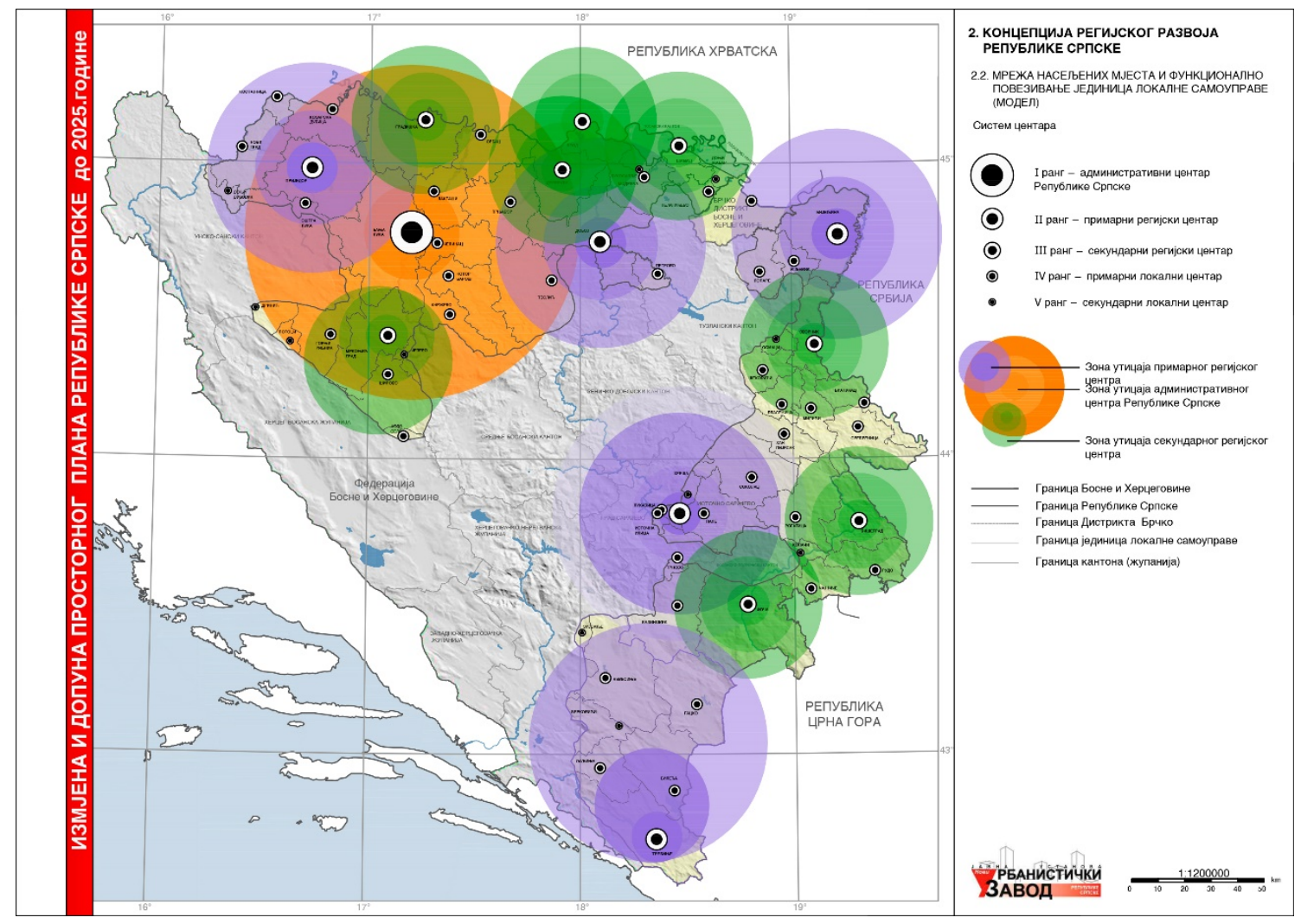

Fig. 7. Cities and urban nuclei according to the Amendments of the Spatial Plan of the Republika Srpska until 2025. Source: New Planning Institute of Republika Srpska, 2014. ${ }^{12}$

The ratification of the "other Sarajevo" was further reinforced in 2008 with the publication of the Spatial Plan of the City of East Sarajevo to 2015 (see Fig. 8) which covered the entire territory of East Sarajevo and included the municipality of Rogatica (City of East Sarajevo, 2008). The plan ratified the city as a combination of urban nuclei of reduced size (between approximately 1,000 and 20,000 inhabitants) which reached a combined total of almost 65,000 inhabitants. ${ }^{13}$ The low-density area is also one of great natural and forestry interest as well as a leisure destination given that it has conserved some of best-known winter sports venues from the Olympics of $1984 .{ }^{14}$ In East Sarajevo, the nuclei of greatest population density are divided between those which belonged to the urban area of the former City of Sarajevo according to the 1986 regional plan, which are Istočna llidža and Istočno Novo Sarajevo, and those which have remained as urban nuclei of the conurbation, Pale and Sokolac. The former ones are adjacent to the current urban area of Sarajevo in the $\mathrm{FBiH}$, turning them into new border areas. These frontier regions are not only territorial limits, but become places in which particular cultural, political and physical relationships develop, both in those territories belonging to their own structures and in those on the other side (Donnan \& Wilson, 1999). In the case of Istočna llidža and Istočno Novo Sarajevo, this is a border area in a process of construction and stabilisation.

12 In 2012 the Urban Institute of Republika Srpska was reformed, rearranging its organisational structure to become the New Planning Institute of Republika Srpska (http://www.nuzrs.com/).

13 The city of East Sarajevo is made up of six municipalities, each with its own population nucleus. From west to east, these are: Istočna llidža 15,233 pop.; Istočno Novo Sarajevo 11,477 pop.; Trnovo - RS 2,192 pop.; Istočni Stari Grad 1,175 pop.; Pale - RS 22,282 pop.; Sokolac 12,607 pop.

14 In 1984 the Winter Olympic Games were held in Sarajevo which brought a certain degree of splendour to the city. 


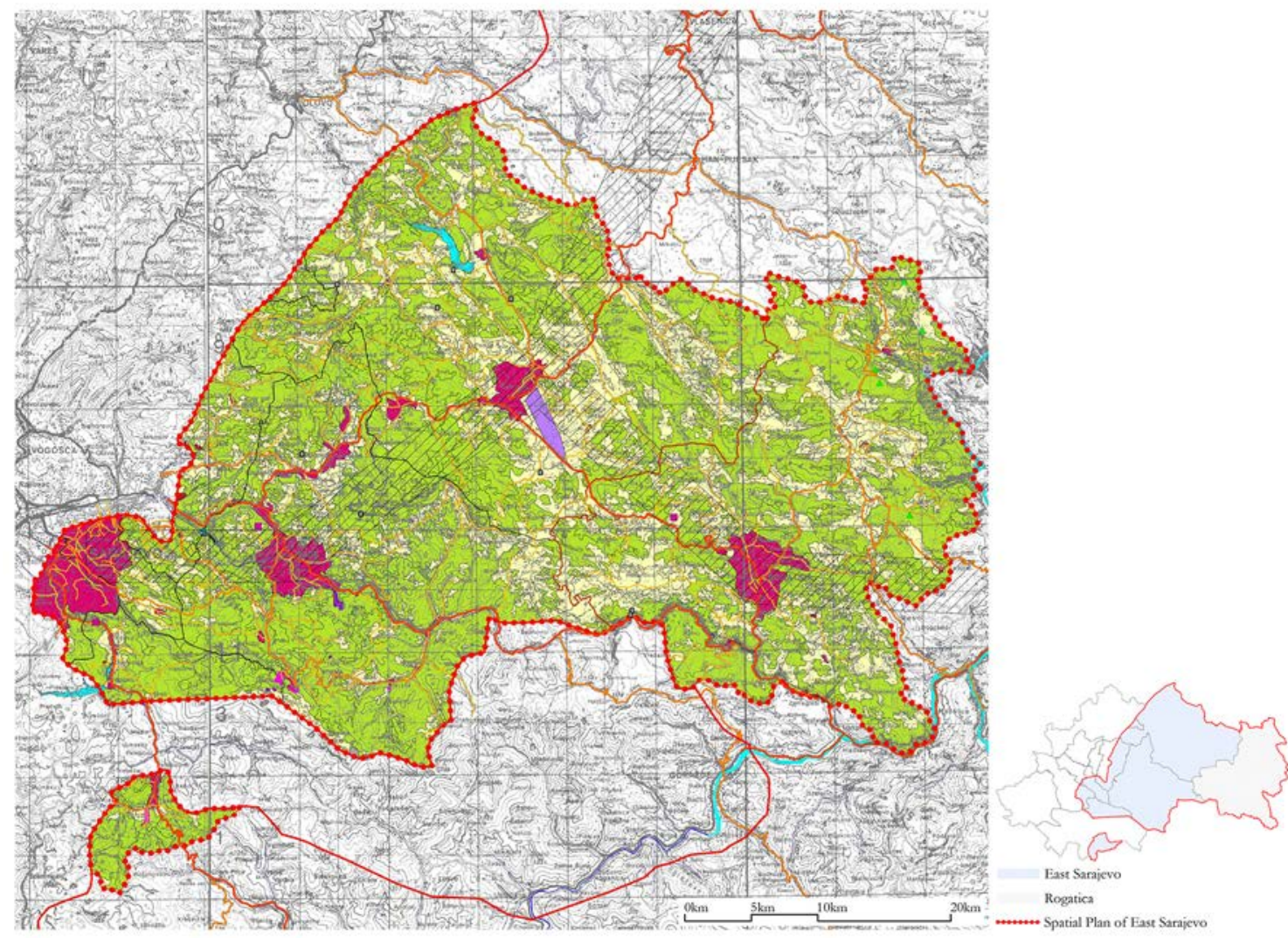

Fig. 8. The Spatial Plan of the City of East Sarajevo to 2015. Source: The Urban Institute of Republika Srpska, 2008.

Both the spatial and urban plan of East Sarajevo (see Fig. 8) have re-zoned areas which the 1986 plan had designated as special zones where civil construction was not permitted (e.g. The barracks of Lukavica) as central and/or residential areas (City of East Sarajevo, 2008). This has also occurred in green zones that have been re-designated as development areas. These new zones, which have been in the process of urbanisation since the beginning of the 2000s, demonstrate the vulnerability of the urban plan of 1986 (see Fig. 6) in the areas belonging to the RS. In fact, the urban plan of 1986 is the only plan that is still based on Sarajevo before the war, in which the IEBL did not exist. Indeed, both the validity of this old urban plan and the approval of those plans analysed above demonstrate the lack of dialogue between the Canton of Sarajevo and the RS, as described in the study by Bassi (2013) regarding the city's duplicated administration.

The territorial construction of East Sarajevo intends to unify the diverse urban nuclei across the region to form a conurbation, promoting the links between the old suburban territories of Sarajevo, the current municipalities of Istočna llidža and Istočno Novo Sarajevo, and the periurban nuclei Pale, Sokolac and Trnovo. The creation of the conurbation is not geographically simple given that the diverse nuclei are positioned at distances of between 25 and $50 \mathrm{~km}$ apart from one another (see Fig. 8). However, in order to formalise the construction of the new city, a new urban identity must be created. For this reason, a large part of the symbolic construction of the new city of East Sarajevo is situated precisely in the border areas of the urban territory, particularly in Istočno Novo Sarajevo and Istočna llidža.

\section{The construction of East Sarajevo and the processes of symbolic homogenisation}

In the urban border areas of Istočno Novo Sarajevo and Istočna llidža the reality is that the ethnic structure has been profoundly affected by the IEBL, causing this tendency to intensify the symbolism of the border lands (Donnan \& Wilson, 1999). The evidence shows precisely this ethnic polarisation on both sides of the limit between the two entities. It is precisely these areas which previously belonged to the nucleus of Sarajevo where this differentiation is most clearly seen. As already mentioned, this area was delimited by the Arbitration Award for Dobrinja I and IV in 2001, ending the conflict between the resident community of Dobrinja in the Federation and the institutions of the RS which defended the legitimacy of the occupation of the residential areas of Dobrinja I and IV, which had already lasted more than five years (Sheridan, 2001). The area had been one of the frontlines of Sarajevo since spring 1992 when the Sarajevo-Romanija forces of the VRS occupied the eastern zone of the neighbourhood (Bećirović, 2002). At the end of the war, the area abandoned by its old residents, who were mainly Bosniaks, remained occupied by Serbobosnian residents, some illegally (Sheridan, 2001). ${ }^{15}$ The conflict consisted in the difficulty which the exact line of demarcation implied. It was the artificial nature of the dividing line which perpetuated the conflict. The institutions of the RS (including the Prime Minister, Mladen Ivanić) claimed that the IEBL ought to coincide

15 The question of property ownership was one of the greatest debates in post-war Bosnia and Herzegovina, linked as much to the change of economic system as to the rights of ownership of the internal displaced population as well as of international refugees. 
with the front line of the battle field, whilst the residents of the FBiH insisted on the right to reclaim their homes. It was precisely the artificiality of the line of the IEBL and the scale at which it was drawn which made the transfer of territory and its definition so difficult. ${ }^{16}$ The conflict was resolved by means of the ruling made by Diarmuid P. Sheridan, the Irish judge selected by the HR, who after months of deliberation drew out the final borderline, authorising a large part of the disputed apartments and school to the Canton of Sarajevo (Sheridan, 2001).

"It would be heartening, if I were to be able to expect that in the future the line would disappear for all practical everyday purposes and that the communities generally, whilst of different ethnic origin, would come together as neighbours and would be welded by time, into a community enjoying the fruits of a re-built Dobrinja I and IV" (Diarmuid P. Sheridan, Arbitrator for Dobrinja IEBL, 17 th April 2001).

Despite the arbitrator's words of hope, since the precise definition of the IEBL in 2001, not only have new prospective plans appeared, drawn both by the RS and by the Canton of Sarajevo (see section 2), but also the construction of a new urban nucleus at Istočno Novo Sarajevo and Istočna llidža has arisen out of the implementation of these plans. The area adjacent to Dobrinja has grown little by little incorporating new housing and services. A large part of the new urban centre was located at the barracks and military zone of Lukavica, converting the buildings into centres for civilian services, and the military land into new areas for private housing development. ${ }^{17}$ In this way, from 2001 up to the present day between 1,500 and 1,700 housing ${ }^{18}$ has been built in the old military zone of Lukavica, along with diverse services of a wider field of reference such as four faculties of the University of East Sarajevo -the faculties of Electrical Engineering, Mechanical Engineering, and Agriculture and the Academy of Music (http://www.ues.rs.ba/). The materialisation of ethnic symbolism has proliferated in the heart of Istočno Novo Sarajevo, where the very barracks of Lukavica, occupied by the VRS during the war and the centre of the military forces which prolonged the siege of the city, were honoured in 2014 as the site of the founding of the new Sarajevo. ${ }^{19}$
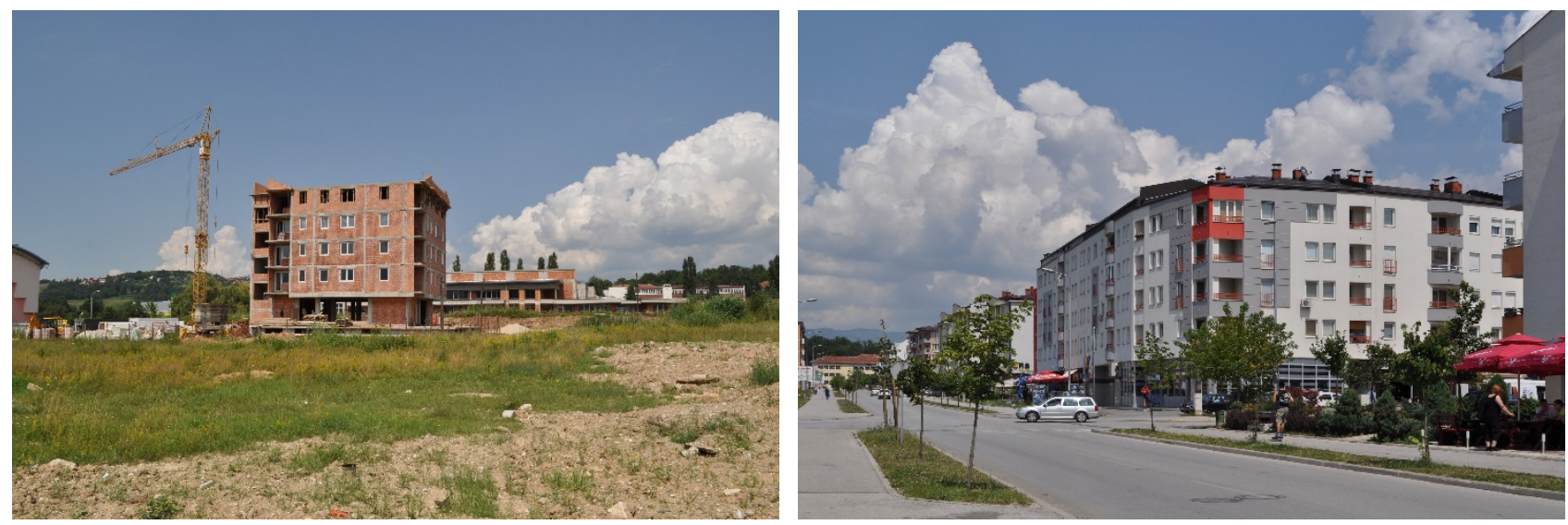

Fig. 10. East Sarajevo under construction, the area of Lukavica, August 2014. Source: the authors.

So, as well as the construction of a new "neighbourhood", the symbolism present in this border area took shape under the influence of a specific ethnic language. The "invisible border" became more visible. On the road to the airport leading to the southeast, exactly along the path of the borderline drawn in 2001, there are respective welcome signs to the East -the Republika Srpska- and to the West -the Canton of Sarajevo. It is worth noting that the sign for the RS (Fig.9 left) is written in Cyrillic ${ }^{20}$ and the sign for the Canton (Fig.9 right) is written in the Latin alphabet (both with their corresponding translations in English). The use of the Cyrillic alphabet further reinforces the presence of the Serbian ethnographic identity. This difference in the use of language and alphabet exemplifies the processes of differentiation which appear on either side of the IEBL, thereby reinforcing the existence of a supposedly invisible border (Toal \& Dahlman, 2011:173).

\footnotetext{
${ }^{16}$ The conflict over the transfer of areas from one entity to the other provoked conflict in other areas of Bosnia and Herzegovina. See also the case of the District of Brčko (Jeffrey, 2006).

17 The land occupation of housing has been compared using cartography from before the war, aerial photographs from 1995, and visual inspection in February 2014, August 2014 and October 2015.

${ }^{18}$ Estimated from the volume of buildings constructed since 2001 in the area of Lukavica and applying the average typology of housing built.

19 In the commemorative plaque, the following statement is written in Cyrillic: "In this place once stood the entrance of the quarters of Slobodan Princip - Seljo of the "JNA". / From 1992-1995 this was the parade ground of the Sarajevo-Romanija section of the Army of the República Srpska. I Since 1996, many thousands of Serbs from Sarajevo have sought refuge here. / Here are the foundations of the Srpsko Municipality of Istočno Novo Sarajevo." (Commemorative plaque, Organization of Veterans of Istočno Novo Sarajevo, June 2014).

${ }^{20}$ During the SFRY, Serbo-Croatian was the official language in four of the six Republics of Yugoslavia, in Croatia, Bosnia and Herzegovina, Serbia and Montenegro. After the Republics separated, each state made its dialect official denominating them as Croatian, Bosnian, Serbian and Montenegrin. Traditionally the Latin alphabet has been used in the Croatian dialect and Cyrillic in the Serbian dialect. For further information, see Corbett \& Browne (2009).
} 

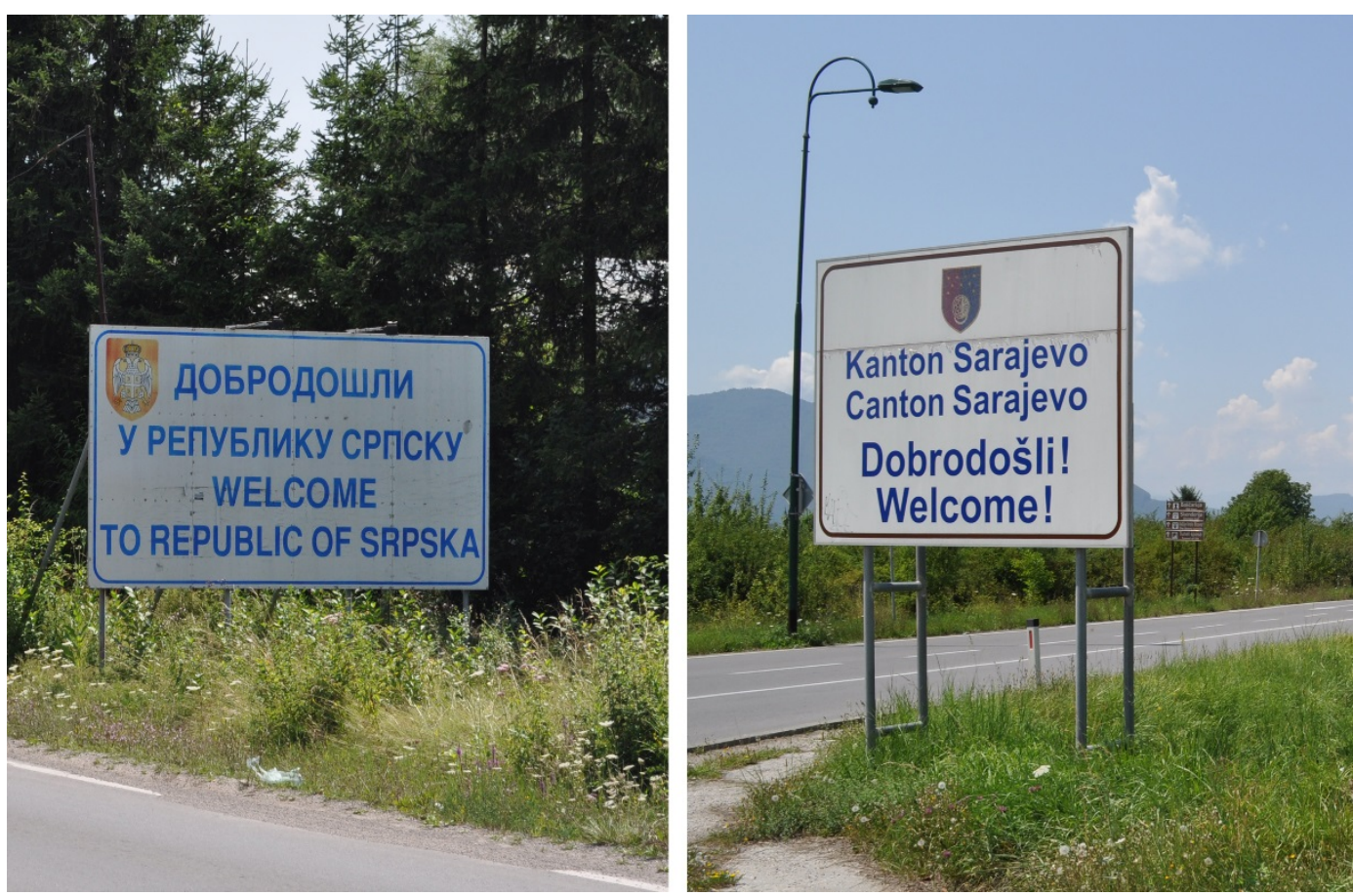

Fig. 9. The M-18 main road at Dobrinja. Left: Welcome sign to the East. Right: Welcome sign to the West. August, 2014. Source: the authors.

In 2014, to commemorate the centenary of the start of the First World War, a bronze statue of Gavrilo Princip, who assassinated the archduke Franz Ferdinand in 1914, was placed in the area of Lukavica. The president of the Republika Srpska, Milorad Dodik, attended the ceremony and stated: "we hereby unveil this monument and send a message that we are proud of our history, of our fight for liberty, for everything that our ancestors did to defend the right to our identity". ${ }^{21}$ However, in the Sarajevo of the Federation, all attributes linked to Gavrilo Princip, the symbol of the Serbian nation, were replaced. At the spot where the Archduke was assassinated, on one of the bridges of the historic centre, the name of Gavrila Princip Street was changed in a process of renewal of street names throughout the historic centre, which also included eradicating all trace of Cyrillic (Robinson et al., 2001). The symbolism induced by the entities is readjusting itself on either side of the IEBL.

It seems that in this small urban area the intensification of cultural symbolism is repeated, as Donnan \& Wilson (1999) commonly detected in border lands. However, as these authors explain, the border can also imply an increase in exchange. In East Sarajevo there are clear tensions between the processes of symbolic homogenisation and those of social and economic exchange. This is due to the fact that the areas of Istočno Novo Sarajevo and Istočna llidža remain partly dependent on the centre of Sarajevo, which is still the area of greatest economic activity and where the largest developments, including shopping malls (e.g., Importanne, Alta, BBI Shopping Centre and Sarajevo City Centre) and office towers (e.g., Avaz Twist Tower and Bosmal City Centre), have recently been developed (Gül \& Dee, 2015). The reality is that whilst a new city centre is being built in the eastern suburban area, the exchange between one area and the other continues. A good example of this is the flow of daily journeys. In order to go from the new residential area of Lukavica to the historic centre of Sarajevo by public transport, the residents of Istočno Novo Sarajevo must go to the neighbourhood of Dobrinja to catch the trolley bus because the line finishes just short of crossing the IEBL -public transport in the Canton of Sarajevo does not reach the neighbourhood of Lukavica. However, despite this lack of transport, the street which links the last trolley bus stop (in the Federation) with the new residential areas of Lukavica (in the RS) has one of the largest flows of pedestrians in the area of Istočno Novo Sarajevo. ${ }^{22}$

\section{Conclusions and implications}

Returning to the question as to whether Sarajevo is a truly divided city, the answer proposed depends first, on how this division is interpreted, and second, on what territory may actually be considered "Sarajevo".

On the one hand, the limits of the former City of Sarajevo have been clearly modified by the DPA. Given that the territory of the earlier ten municipalities no longer pertains to one single entity, an irrevocable administrative division exists. As has been repeatedly shown in the various masterplans produced by the administrations of both the Canton of Sarajevo and the RS, the creation of the IEBL has determined the reality of urban planning and the prospects for the city. The new city of East Sarajevo has been born out of the will in the RS to build a Serbian Sarajevo. However the geographic reality has caused the city of East Sarajevo to be composed of diverse population centres across an area which is largely rural and forested, making them difficult to read as a single urban entity. Therefore, this desire to build a new Sarajevo has encouraged that in the area of Istočno Novo Sarajevo adjacent to the Federation, a new residential area has been built with a distinct ethnic symbolism intending to present itself as the new urban nucleus of East Sarajevo.

21 Declarations of the President of the Republika Srpska, Milorad Dodik, 27th of June 2014, documented by Edina Kamenica in: http://www.oslobodjenje.ba/vijesti/bih/radmanovic-i-dodik-otkrili-spomenik-gavrilu-principu.

22 Visual inspection conducted in February 2014, August 2014 and October 2015. 
On the other hand, the urban area of the Sarajevo of 1992 has remained in the Canton. Taking into account the areas affected by the IEBL in the urban plan of 1986, only Dobrinja and the East of llidža have lost urban zones (in the case of Dobrinja this was only five blocks, thanks to the ruling of the Arbitration Award). In this sense, the urban part of Sarajevo remains largely "united" in the Canton, whereas other changes, which have taken place since the end of the war, have been caused by urban processes linked mainly to reconstruction, the change of economic system, to foreign investment and to the arrival of internal displaced people and refugees.

The geographic arbitrariness of the IEBL has become a double-edged sword. Over more than twenty years, the existence of the DPA has led to the stabilisation of the Entities, and if the RS would not make sense without the DPA, neither would East Sarajevo without the IEBL. So whilst the new construction of East Sarajevo is located along the border, the artificial nature of the IEBL makes the territory resulting from the division difficult to join together to create a functional urban area spread across the six municipalities of the East. Both Istočno Novo Sarajevo and Istočna llidza are geographically adjacent to the urban area of the Canton of Sarajevo, maintaining an economic and functional link to the Sarajevo of the Federation.

The possible futures of the city are uncertain, given that despite the political tendency to ratify the division, the economic and geographic reality in both the Sarajevo of the Federation and East Sarajevo appears to be more complex.

\section{Acknowledgments}

The authors wish to thank Gordana Memisević, Ervin Prasiljević, Nataša Pelja-Tabori, and Zina Ruždić from the Office for Development Planning of the Canton of Sarajevo; Vesna Hercegovac-Pašić for her general overview of the urban planning in Sarajevo; Midhat Aganović for his memories of the city from the past to the present; the architects from Filter Architecture studio, specially Ibrica Jasarević and Vedad Islambegović; and Vesna Simić and Dejan Todorović from the New Planning Institute of Republika Srpska. The authors would also like to thank Andrew Kirby and Ali Modarres for their dedicated editorial assistance and the anonymous reviewer for comments on a draft version of the paper.

\section{References}

Aganović, M. \& Krzik, T. (2006). Valorizacija i sanacija bespravno izgrađenih objekata. Za potrebe izrade prostornog Plana Kantona Sarajevo za period 2003. do 2023. godine. Sarajevo: Institut za arhitekturu, urbanizam i prostorno planiranje Sarajevo.

Andjelić, N. (2003). Bosnia-Herzegovina: the end of a legacy. London \& Portland: Frank Cass.

Andreas, P. (2008). Blue helmets and black markets: the business of survival in the siege of Sarajevo. New York: Cornell University Press.

Andrusz, G., Harloe, M., \& Szélényi, I. (Eds.) (1996). Cities after socialism: Urban and regional change and conflict in post-socialist societies. Oxford: Blackwell Publishers.

Bădescu, G. (2014). City makers, urban reconstruction and coming to terms with the past in Sarajevo. In S. Garcia, \& B. Kotzen (Eds.). Reconstructing Sarajevo. Negotiating Socio-Political Complexity. London: LSE Cities Programme \& The Ove Arup Foundation, pp. 14-21.

Bassi, E., (2013). Sarajevo: divided or redoubled? Regulations, representations and practices across the boundary. PhD diss. Milano: Università degli Studi di Milano - Bicocca.

Bećirović, H. (2002). Dobrinjska ratna drama. Sarajevo: Unija veterana.

Benvenisti, M. (1982). Administering conflicts: Local government in Jerusalem and Belfast. PhD diss. Cambridge, Massachusetts: Kennedy School of Government, Harvard University.

Benvenisti, M. (1986). Conflicts and contradictions. New York: Villard Books.

Berman, D. M. (2005). The war schools of Dobrinja: schooling under siege in a Sarajevo community. Pittsburgh: Center for Russian and East European Studies.

Berman, D. M. (2007). The war schools of Dobrinja: reading, writing, and resistance during the siege of Sarajevo. San Francisco: Caddo Gap Press.

Bollens, S. A. (1999). Urban peace-building in divided societies: Belfast and Johannesburg. Boulder, Colorado: Westview Press.

Bollens, S. A. (2000). On narrow ground: urban policy and ethnic conflict in Jerusalem and Belfast. Albany, New York: State University of New York Press.

Bollens, S. A. (2007). Cities, nationalism, and democratization. London: Routledge.

Bose, S. (2002). Bosnia after Dayton: nationalist partition and international intervention. London: C. Hurst.

Bublin, M. (2006). Sarajevo u istoriji: od neolitskog naselja do metropolisa. Sarajevo: Buybook.

Burg, S. L., \& Shoup, P. S. (1999). The War in Bosnia-Herzegovina: Ethnic Conflict and International Intervention. Armonk, Nueva York: M. E. Sharpe.

Calame, J., \& Charlesworth, E. (2009). Divided cities: Belfast, Beirut, Jerusalem, Mostar, and Nicosia. Philadelphia: University of Pennsylvania Press.

Corbett, G., \& Browne, W. (2009). Serbo-Croat: Bosnian, Croatian, Montenegrin, Serbian pp. In B. Comrie (Ed.). The World's Major Languages. Second Edition. London \& New York: Routledge, pp. 330-346.

Donia, R. J. (2006). Sarajevo. A Biography. London: C. Hurst \& Co.

Donnan, H., \& Wilson, T. M. (1999). Borders: frontiers of identity, nation and state. Oxford: Berg.

Garcia, S., \& Kotzen, B. (Eds.) (2014). Re-constructing Sarajevo. Negotiating Socio-Political Complexity. London: LSE Cities Programme \& The Ove Arup Foundation.

Gül, M. \& Dee, J. (2015). Sarajevo - A city profile. Cities, 43 (2015), 152-166.

Hasić, T. (2004). Reconstruction Planning in Post-Conflict Zones: Bosnia and Herzegovina and the International Community. Stockholm: The Royal Institute of Technology.

Hirt, S. (2006). Post-Socialist urban forms: notes from Sofia. Urban Geography, 27 (5), 464-488.

Hirt, S. (2008). Landscapes of post-modernity: changes in the built fabric of Belgrade and Sofia since the end of Socialism. Urban Geography, 29 (8), 785-810.

ICG (1997). Going Nowhere Fast. Refugees and Internally Displaced Persons in Bosnia and Herzegovina. ICG Bosnia Report, $23,1-67$. 
Jeffrey, A. (2006). Building state capacity in post-conflict Bosnia and Herzegovina: The case of Brčko District. Political Geography, 25 (2006), $203-$ 227.

Jeffrey, A. (2012). The Improvised State: Sovereignty, Performance and Agency in Dayton Bosnia. Malden, Massachusetts: John Wiley \& Sons.

Karčić, H. (2010a). Globalisation and Islam in Bosnia: Foreign Influences and their Effects. Totalitarian Movements and Political Religions, 11 (2), 151-166.

Karčić, H. (2010b). Islamic Revival in Post-Socialist Bosnia and Herzegovina: International Actors and Activities. Journal of Muslim Minority Affairs, 30 (4), 519-534.

Klein, M. (2001). Jerusalem: The Contested City. New York: New York University Press.

Klemenčić, M. (1994). Territorial proposals for the settlement of the war in Bosnia-Herzegovina. Boundary and Territory Briefing, 1 (3), 1-74.

Klemenčić, M. (2000-2001). The Boundaries. Internal Order and Identities of Bosnia and Herzegovina. Boundary \& Security Bulletin, 8 (4), 63-71.

Kovács, Z. (1999). Cities from state socialism to global capitalism: an introduction. GeoJournal, 49 (1), 1-6.

Kumar, K. (Ed.) (1997). Rebuilding Societies After Civil War: Critical Roles for International Assistance. Boulder, Colorado: Lynne Rienner Publishers.

Kurto, N. (1998). Arhitektura Bosne i Hercegovine: razvoj bosanskog stila. Sarajevo: Međunarodni centar za mi.

Kurtović, E., Softić, S., Fetahagić, M., Memišević, G. (2013). Strategic Planning at Cantonal Level - Step closer to EU: Canton Sarajevo Example. In J. Osmankovic \& M. Pejanovic. Proceedings of the International Scientific Conference: Local Economic and Infrastructure Development of SEE in the Context of EU Accession. Sarajevo: Academy of Sciences and Arts of Bosnia and Herzegovina.

Maček, I. (2000). War Within: Everyday Life in Sarajevo under Siege. Uppsala: Uppsala Universitet

Maček, I. (2009). Sarajevo under Siege: Anthropology in Wartime. Philadelphia: University of Pennsylvania Press.

Malcolm, N. (1994). Bosnia: a short history. London: Papermac.

Marcuse, P. (1993). What's So New About Divided Cities? International Journal of Urban and Regional Research, 17 (3), 355-365.

Martín-Díaz, J. (2014). Urban restructuring in post-war contexts: the case of Sarajevo. Hungarian Geographical Bulletin, 63 (3), $303-317$.

National Assembly of Republika Sprska (1992). The Constitution of Republika Srpska. Official Gazette of Republika Srpska, 3 (1992).

Robinson, G. M., Engelstoft, S. \& Pobrić, A. (2001). Remaking Sarajevo: Bosnian nationalism after the Dayton accord. Political Geography, 20 (2001), $957-980$.

Sheridan, D. P. (2001). Arbitration Award of Dobrinja I and IV. Statement, 17th April 2001. Sarajevo: OHR. On-line: $<$ http://www.ohr.int/?ohr archive=arbitration-award-for-dobrinia-i-and-iv\&lang=en> Last accessed 30.12.2015

Silber, L. \& Little, A. (1996). The death of Yugoslavia. London: Penguin \& BBC books.

Softić, E. (1994). Sarajevski dani, sarajevske noći: dnevnik i pisma 1992-94. Zagreb: V.B.Z.

Sorkin, M. (Ed.) (2002). The Next Jerusalem: sharing the divided city. New York: The Monacelli Press.

Stanilov, K. (Ed.) (2007). The Post-Socialist City: Urban Form and Space Transformations in Central and Eastern Europe after Socialism. Dordrecht, The Netherlands: Springer.

Stefansson, A. (2007). Urban Exile: Locals, Newcomers and the Cultural Transformation of Sarajevo. In X. Bougarel, E. Helms \& G. Duijzings (Eds.) The New Bosnian Mosaic: Identities, Memories and Moral Claims in a Post-War Society. Aldershot: Ashgate Publishing, pp. 59-77.

Toal, G. \& Dahlman, C. T. (2011). Bosnia Remade: Ethnic Cleansing and its Reversal. New York: Oxford University Press.

Tsenkova, S. \& Nedović-Budić, Z. (Ed.) (2006). The Urban Mosaic of Post-Socialist Europe: Space, Institutions and Policy. Heidelberg \& New York: Physica-Verlag.

Tsenkova, S. \& Polanska, D. V. (2014). Between state and market: housing policy and housing transformation in post-socialist cities. GeoJournal, 79 (2014), 401-405.

UN (1995). General Framework Agreement for Peace in Bosnia and Herzegovina (Dayton Agreement). UN-Department of Political Affairs. On-line: $<$ http://peacemaker.un.org/bosniadaytonagreement95 $>$ Last accessed 30.12.2015

\section{Spatial and Urban Plans}

Canton of Sarajevo (2006). Prostorni Plan Kantona Sarajevo za period od 2003. do 2023. Godine (Spatial Plan of the Canton of Sarajevo 20032023). Sarajevo: Zavod za planiranje razvoja Kantona Sarajevo (Office for Development Planning of the Canton of Sarajevo).

City of East Sarajevo (2008). Prostorni plan Grada Istočno Sarajevo do 2015. godine (Spatial Plan of the City of East Sarajevo to 2015). Banja Luka: Urbanistički zavod Republike Srpske (Urban Institute of Republika Srpska).

City of Sarajevo (1986a). Prostorni plan Grada Sarajeva za period 1986-2015 godine (Spatial Plan of the City of Sarajevo for the period 1986-2015). Sarajevo: Zavod za planiranje razvoja Grada Sarajevo (Office for Development Planning of the City of Sarajevo).

City of Sarajevo (1986b). Urbanistički plan Grada Sarajeva za urbano područje Sarajevo, za period od 1986. do 2015. godine (Urban plan of the City of Sarajevo for the urban area of Sarajevo, for the period from 1986 to 2015). Sarajevo: Zavod za planiranje razvoja Grada Sarajevo (Office for Development Planning of the City of Sarajevo).

National Assembly of Republika Srpska (2014). Izmjena i dopuna prostornog Plana Republike Srpske do 2025. godine (Amendments of the Spatial Plan of the Republika Srpska until 2025). Banja Luka: Novi urbanisticki zavod Republike Srpske (New Planning Institute of Republika Srpska).

\section{Websites}

Amendments of the Spatial Plan of the Republika Srpska until 2025, <http://www.nuzrs.com/izmjene-i-dopune-pprs-do-2025/> Last accessed 15.06.2015

Bosnian Census 2013, <http://www.popis2013.ba/index.php/en/> Last accessed 13.12.2015

Fama Collection, <http://www.famacollection.org/> Last accessed 14.12.2015

Office for Development Planning of the City of Sarajevo, <http://zpr.ks.gov.ba/> Last accessed 21.11.2015

Office of the High Representative, <http://www.ohr.int/> Last accessed 13.12.2015

Oslobodjenje Journal, <http://www.oslobodjenje.bal> Last accessed 17.12.2015

Nato, SFOR Implementation, <http://www.nato.int/sfor/index.htm> Last accessed 13.12 .2015

New Planning Institute of Republika Srpska, <http://www.nuzrs.com/> Last accessed 13.07.2015

Spatial Plan of the Canton of Sarajevo, 2003-2023, <http://zpr.ks.gov.ba/sites/zpr.ks.gov.ba/files/pp/prostorni.htm> Last accessed 14.06 .2015 
University of East Sarajevo, <http://www.ues.rs.ba/> Last accessed 13.12.2015

Urban Plan of the City of Sarajevo 1986-2015, <http://zpr.ks.gov.ba/prostorno-planska-dokumentacija/urbanisticki-plan> Last accessed 13.07.2015 